\title{
Electrochemical and structural characterization of titanium-substituted manganese oxides based on $\mathrm{Na}_{0.44} \mathrm{MnO}_{2}$
}

\author{
Marca M. Doeff, ${ }^{\mathrm{a}}$ Thomas J. Richardson, ${ }^{\mathrm{b}}$ and Kwang-Taek Hwang ${ }^{\mathrm{a}}$ \\ ${ }^{\mathrm{a}}$ Materials Sciences Division \\ ${ }^{\mathrm{b}}$ Environmental Energy Technologies Division \\ Lawrence Berkeley National Laboratory \\ University of California \\ Berkeley, CA 94720
}

\begin{abstract}
A series of titanium-substituted manganese oxides, $\mathrm{Li}_{\mathrm{x}} \mathrm{Ti}_{\mathrm{y}} \mathrm{Mn}_{1-\mathrm{y}} \mathrm{O}_{2}(\mathrm{y}=0.11,0.22$, $0.33,0.44$, and 0.55 ) with the $\mathrm{Na}_{0.44} \mathrm{MnO}_{2}$ structure were prepared from $\mathrm{Na}_{\mathrm{x}} \mathrm{Ti}_{\mathrm{y}} \mathrm{Mn}_{1-\mathrm{y}} \mathrm{O}_{2}$ $(\mathrm{x} \approx 0.44)$ precursors. The electrochemical characteristics of these compounds, which retain the unique double-tunnel structure during ion exchange, were examined in lithium/polymer electrolyte cells operating at $85^{\circ} \mathrm{C}$. All of the substituted cathode materials intercalated lithium reversibly, with $\mathrm{Li}_{\mathrm{x}} \mathrm{Ti}_{0.22} \mathrm{Mn}_{0.78} \mathrm{O}_{2}$ exhibiting the highest capacity in polymer cells, about $10-20 \%$ greater than that of unsubstituted $\mathrm{Li}_{\mathrm{x}} \mathrm{MnO}_{2}$ made from $\mathrm{Na}_{0.44} \mathrm{MnO}_{2}$. In common with $\mathrm{Li}_{\mathrm{x}} \mathrm{MnO}_{2}$, the Ti-substituted materials exhibited good capacity retention over one hundred or more cycles, with some compositions exhibiting a fade rate of less than $0.03 \%$ per cycle.
\end{abstract}

Keywords: manganese oxides; cathodes; $\mathrm{Na}_{0.44} \mathrm{MnO}_{2}$; lithium rechargeable batteries 


\section{Introduction}

$\mathrm{Li}_{\mathrm{x}} \mathrm{MnO}_{2}$ with the $\mathrm{Na}_{0.44} \mathrm{MnO}_{2}$ structure has recently been used as a cathode material in both lithium/liquid electrolyte and lithium/polymer cells at $85^{\circ} \mathrm{C}[1,2]$. Little or no capacity fading is seen during prolonged cycling in either configuration. The remarkable reversibility is particularly noteworthy in the elevated temperature cells, because the spinel $\mathrm{LiMn}_{2} \mathrm{O}_{4}$ tends to lose capacity rapidly when cycled in acidic electrolytes above $55^{\circ} \mathrm{C}$ [3]. Other desirable features of this material include phase stability to about $400^{\circ} \mathrm{C}$ [4], resistance to degradation during over-charge or -discharge [5], and the ability to be discharged rapidly (up to 5C rate) with good capacity retention [1]. The characteristics of robustness and excellent reversibility are particularly attractive when the requirements for hybrid electric vehicle (HEV) batteries are taken into consideration; cost constraints mandate the use of inexpensive electrodes such as manganese oxides, but materials must demonstrate abuse-tolerance and be able to withstand thousands of high-power, shallow cycles. For applications such as electric vehicles (EVs) or consumer devices, however, a higher specific energy may be required than that currently provided by this material.

If lithium ions were constrained to the equivalent sodium sites in $\mathrm{Li}_{x} \mathrm{MnO}_{2}$ with the $\mathrm{Na}_{0.44} \mathrm{MnO}_{2}$ structure, the theoretical capacity would be $193 \mathrm{mAh} / \mathrm{g}$, corresponding to a composition range of $x=0$ to 0.66 . There is, however, evidence that more of the smaller Li ions can be inserted [4], and that the lithium tunnel sites are different from those occupied by sodium [12]. In practical cells, less lithium is cycled because not all the lithium ions in the structure can be extracted before oxidation of polymer or liquid electrolytic solutions takes place. The reversible capacity depends upon the cell 
configuration and temperature, current density, voltage limits, and how the sample is prepared. $120 \mathrm{mAh} / \mathrm{g}$ is the maximum observed for ambient temperature liquid electrolyte cells discharged at $\mathrm{C} / 3$ rates between 4.2 and $2.5 \mathrm{~V}$. The capacity of ion- exchanged materials (prepared prior to incorporation in cells) declines as the sodium content decreases. $\mathrm{Na}_{0.44} \mathrm{MnO}_{2}$ can deliver up to $150 \mathrm{mAh} / \mathrm{g}$ in sodium/polymer cells [6] or 140 $\mathrm{mAh} / \mathrm{g}$ in lithium/polymer cells (N.B., some ion exchange occurs in situ [7]). This compares to about 95-100 mAh/g for fully exchanged $\mathrm{Li}_{x} \mathrm{MnO}_{2}$ in lithium/polymer cells under the same conditions. Ion exchange also has the effect of steepening the discharge profile of these compounds, thereby decreasing utilization between practical cell voltage limits.

Differential capacity plots obtained from potential step experiments on lithium cells containing compounds with the $\mathrm{Na}_{0.44} \mathrm{MnO}_{2}$ structure show the variation in electrochemical characteristics with extent-of-exchange; specifically, the intensities, breadths, positions, and numbers of peaks are sensitive to sodium content. A possible explanation for these differences is that sodium ions prop open the tunnels (as evidenced by the dependence of unit cell volume on sodium content), allowing improved access by lithium ions [8]. While the higher capacity is desirable, slow exchange occurs in situ, causing steepening of the discharge profile and decreasing capacity delivered between set voltage limits as cells are cycled. To increase capacity but maintain the excellent cycling characteristics of $\mathrm{Li}_{x} \mathrm{MnO}_{2}$ with the $\mathrm{Na}_{0.44} \mathrm{MnO}_{2}$ structure, other methods besides using sodium ions to increase unit cell size and alter the discharge characteristics were investigated. The purpose of the current study was to investigate of the effect of partial substitution of titanium for manganese on the discharge and cycling characteristics. 


\section{Experimental}

$\mathrm{Na}_{\mathrm{x}} \mathrm{Ti}_{\mathrm{y}} \mathrm{Mn}_{1-\mathrm{y}} \mathrm{O}_{2}$ compounds with $\mathrm{x} \approx 0.44$ and $\mathrm{y}=0.11,0.22,0.33,0.44$, and 0.55 were made by heating together well-mixed powders of $\mathrm{Na}_{2} \mathrm{Ti}_{3} \mathrm{O}_{7}, \mathrm{Mn}_{2} \mathrm{O}_{3}$, and $\mathrm{Na}_{2} \mathrm{CO}_{3}$ in the desired proportions at $850^{\circ} \mathrm{C}$ for ten hours. A starting ratio of $\mathrm{Na}$ : $(\mathrm{Mn}+\mathrm{Ti})$ of 0.47 was used to compensate for sodium loss at elevated temperatures. In cases where an $\mathrm{Mn}_{2} \mathrm{O}_{3}$ impurity was detected, the powders were re-ground with $\mathrm{NaOH}$ and re-fired. The products obtained after this treatment were phase-pure, and black or brown-black in color. Some powders were attrition-milled for eight hours prior to electrochemical testing. One sample of $\mathrm{Na}_{\mathrm{x}} \mathrm{Ti}_{0.22} \mathrm{Mn}_{0.78} \mathrm{O}_{2}$ was prepared at $1000^{\circ} \mathrm{C}$. In this case, the slight excess of sodium led to the formation of a small amount $(<5 \%)$ of a sodium-rich layered phase similar to $\mathrm{Na}_{0.7} \mathrm{MnO}_{2+\mathrm{y}}$ [9]. This material was prepared for structural studies and was not tested in electrochemical cells.

$\mathrm{Na}_{\mathrm{x}} \mathrm{Ti}_{0.22} \mathrm{Mn}_{0.78} \mathrm{O}_{2}$ was also prepared by a sol-gel technique. First, $200 \mathrm{~mL}$ of a $0.2 \mathrm{M}$ solution of titanium isopropoxide (Aldrich Chemical Company) was mixed with 200 cc of distilled water, maintained at $50{ }^{\circ} \mathrm{C}$ under reflux, and stirred for four hours. The $\mathrm{pH}$ was then adjusted to 3 by adding nitric acid to the clear sol. Manganese nitrate and sodium hydroxide were then added to the stirred solution, which turned brown. A small amount (approximately 2\% w/w) of polyethylene glycol $(\mathrm{MW}=10,000)$ was added to the solution to aid in dispersion [10]. After three days of stirring, the solution was filtered, dried, and calcined for four hours at $850{ }^{\circ} \mathrm{C}$. A small amount of a layered phase $(<5 \%)$ was detected in the product, but the major phase was the expected tunnel compound.

$\mathrm{Na}_{\mathrm{x}} \mathrm{Ti}_{\mathrm{y}} \mathrm{Mn}_{1-\mathrm{y}} \mathrm{O}_{2}$ powders were ion-exchanged by heating them in a molten saltmixture of $68-\mathrm{mol} \% \mathrm{LiNO}_{3} / 32-\mathrm{mol}_{\%} \mathrm{KNO}_{3}$ at 230 to $250^{\circ} \mathrm{C}$. A 2 to 5 -fold excess of the 
Li salt was used, and the supernatant liquid was poured out and replaced twice during the exchange, which typically took 48 hours. The powders were washed well with distilled water and dried for several days at $140^{\circ} \mathrm{C}$. X-ray diffraction (XRD) analysis indicated that the exchanged compounds were isomorphous with the sodium-containing precursors. Layered contaminants such as that found in the sol-gel preparation converted to spinel upon ion exchange, but the majority phase was always a material with the $\mathrm{Na}_{0.44} \mathrm{MnO}_{2}$ structure.

The insolubility of $\mathrm{Na}_{\mathrm{x}} \mathrm{Ti}_{\mathrm{y}} \mathrm{Mn}_{1-\mathrm{y}} \mathrm{O}_{2}$ and $\mathrm{Li}_{\mathrm{x}} \mathrm{Ti}_{\mathrm{y}} \mathrm{Mn}_{1-\mathrm{y}} \mathrm{O}_{2}$ compounds in neat or aqueous acids precluded elemental analysis by atomic absorption. Instead, thin pellets of the compounds of interest were pressed and analyzed by laser ablation/mass spectroscopy [11]. Pellets of $\mathrm{MnO}_{2}$ and $\mathrm{Li}_{\mathrm{x}} \mathrm{Mn}_{2} \mathrm{O}_{4}$ samples of known compositions were used as references. This technique tended to overestimate sodium content in the $\mathrm{Na}_{\mathrm{x}} \mathrm{Ti}_{\mathrm{y}} \mathrm{Mn}_{1-\mathrm{y}} \mathrm{O}_{2}$ samples (most likely because of the lack of a suitable sodium-containing reference for these compounds). No sodium was detected, however, in fully-exchanged $\mathrm{Li}_{\mathrm{x}} \mathrm{Ti}_{\mathrm{y}} \mathrm{Mn}_{1-\mathrm{y}} \mathrm{O}_{2}$ samples.

Nominal compositions and experimental values for titanium and lithium content obtained by laser/ablation mass spectroscopy for the compounds studied are presented in Table I. The agreement is good, although there are deviations at high Ti content that may be due to the use of manganese oxide references that do not contain titanium. The nominal compositions are used throughout this paper. Scanning electron microscopy (Microspec ISI-DS 130C dual stage SEM) was used to observe the particle morphology of the samples. X-ray powder diffraction patterns were obtained using a Siemens D500 
diffractometer with $\mathrm{Cu} \mathrm{K} \alpha$ radiation and a diffracted beam monochromator. Cell parameters and atomic positions were determined by Rietveld refinement.

Components for cells were fabricated and liquid electrolyte and polymer electrolyte cells assembled as previously described [1]. Polymer cell assemblies were equilibrated at $85 \pm 0.5^{\circ} \mathrm{C}$ in a convection oven for at least one hour prior to testing. A MacPile II (Bio-Logic, SA, Claix, France) was used for both galvanostatic and potentiostatic experiments. For electrochemical potential spectroscopy experiments (ECPS), the potential was stepped $10 \mathrm{mV}$ every 4 hours, or until the current had decreased to 1/1000 of its initial value, between 2.5 and $3.5 \mathrm{~V}$. Galvanostatic charges, discharges and cycling experiments were carried out between set voltage limits (most commonly between 3.6 and $2.5 \mathrm{~V}$ ), with rest periods of 0.25 to 1 hour between half cycles.

\section{Results and Discussion}

\section{Structure and Composition of Electrode Materials}

The structure of the parent compound, $\mathrm{Na}_{0.44} \mathrm{MnO}_{2}$, is shown in Figure 1 . Columns of edge-sharing $\mathrm{MnO}_{5}$ square pyramids and sheets of edge-sharing $\mathrm{MnO}_{6}$ octahedra two and three units in width extend parallel to the c-axis. These are connected by corner sharing to form two types of tunnels containing sodium ions. Na1 sites are located in the smaller tunnels, and $\mathrm{Na} 2$ and $\mathrm{Na} 3$ in the large S-shaped tunnels. There are five sites with different symmetries for the manganese ions. Mn1 is located at special position $(0,0.5,0)$ in the central $\mathrm{MnO}_{6}$ octahedron in the row of three and comprises $11 \%$ of the total manganese content. The four other types of manganese (Mn2, Mn3, and Mn5 in $\mathrm{MnO}_{6}$ octahedra and $\mathrm{Mn} 4$ in the square pyramid) each comprise $22 \%$ of the total $\mathrm{Mn}$ 
content. In as-prepared $\mathrm{Na}_{0.44} \mathrm{MnO}_{2}, \mathrm{Mn}$ in the $\mathrm{Mn} 1, \mathrm{Mn} 2$, and $\mathrm{Mn} 3$ sites is in the +4 oxidation state, $\mathrm{Mn}$ in the Mn4 and Mn5 sites is in the +3 oxidation state, the sodium sites in the small tunnels are nearly fully occupied, while in the larger tunnels the Na2 sites are about two-thirds full, and the Na3 sites are about one-third full [4, 12].

$\mathrm{Na}_{4} \mathrm{Mn}_{4} \mathrm{Ti}_{5} \mathrm{O}_{18}$ was first prepared from a melt of $\mathrm{TiO}_{2}$, sodium oxalate, and $\mathrm{MnO}_{2}$ at $1200^{\circ} \mathrm{C}$ by Mumme [13] (prior to discovery of $\mathrm{Na}_{0.44} \mathrm{MnO}_{2}$ ). A single crystal study verified that it has the structure shown in Figure 1 , with $\mathrm{Ti}^{4+}$ ions most likely located where Mn1, Mn2, and Mn3 are indicated, based on symmetry and bond lengths. The existence of this material suggests that it should be possible to prepare materials isostructural to $\mathrm{Na}_{0.44} \mathrm{MnO}_{2}$, in which manganese ions on specific sites are replaced with titanium. We were able to prepare $\mathrm{Na}_{\mathrm{x}} \mathrm{Ti}_{\mathrm{y}} \mathrm{Mn}_{1-\mathrm{y}} \mathrm{O}_{2}(\mathrm{x} \approx 0.44, \mathrm{y}=0.11,0.22,0.33,0.44$, and 0.55 ) by solid state reactions at $850^{\circ}$ and $1000^{\circ} \mathrm{C}$. Additionally, $\mathrm{Na}_{\mathrm{x}} \mathrm{Ti}_{0.22} \mathrm{Mn}_{0.78} \mathrm{O}_{2}$ was prepared by a sol-gel method.

The XRD patterns of $\mathrm{Na}_{\mathrm{x}} \mathrm{Ti}_{\mathrm{y}} \mathrm{Mn}_{1-\mathrm{y}} \mathrm{O}_{2}$ compounds prepared at $850{ }^{\circ} \mathrm{C}$ are shown in Figure 2. Changes in the cell parameters as the titanium content increases cause shifting, overlapping, and/or splitting of the peaks in these complex patterns, but the structural similarity of the compounds is still evident. The $\mathrm{Na}_{\mathrm{x}} \mathrm{Ti}_{0.22} \mathrm{Mn}_{0.78} \mathrm{O}_{2}$ sample prepared at $1000{ }^{\circ} \mathrm{C}$ (pattern not shown) contains small amounts of a sodium-rich layered phase and $\mathrm{Mn}_{3} \mathrm{O}_{4}$. Otherwise, the pattern is similar to that of material prepared at $850{ }^{\circ} \mathrm{C}$. The major phase in each sample were indexed and refined in space group Pbam. Figure 3 shows the experimental, calculated, and difference patterns for $\mathrm{Na}_{0.35} \mathrm{Mn}_{0.55} \mathrm{Ti}_{0.44} \mathrm{O}_{2}$. The XRD pattern for the sol-gel $\mathrm{Na}_{\mathrm{x}} \mathrm{Ti}_{0.22} \mathrm{Mn}_{0.78} \mathrm{O}_{2}$ sample resembled those of samples prepared by conventional means, but the lines were much broader due to the small crystallite size, had 
multiple maxima, suggesting a mixture of phases, and contained reflections due to a sodium-rich layered compound.

Structural parameters and sodium contents obtained from the refinements are listed in Table 2. The sodium content decreased with increasing titanium content in samples prepared at $850{ }^{\circ} \mathrm{C}$, but was lower than expected for $\mathrm{Na}_{\mathrm{x}} \mathrm{Ti}_{0.22} \mathrm{Mn}_{0.78} \mathrm{O}_{2}$ prepared at $1000{ }^{\circ} \mathrm{C}$. The phase purity was very sensitive to the $\mathrm{Na}(\mathrm{Mn}+\mathrm{Ti})$ ratios of the reactants. When the ratio was low, an $\mathrm{Mn}_{2} \mathrm{O}_{3}$ impurity was observed, and when high, a sodium-rich layered phase similar to $\mathrm{Na}_{0.7} \mathrm{MnO}_{2+\mathrm{y}}$ appeared. This indicates that, at elevated temperatures, there is little or no composition range for sodium in the tunnel phase, although the exact value varied with differing reaction conditions (e.g., temperature, Mn:Ti ratio, oxygen partial pressure). As the occupancies of the sodium sites vary, it is accommodated by a change in the average oxidation state of manganese. This may explain the slight discrepancy in composition observed by other researchers who prepared " $\mathrm{Na}_{0.44} \mathrm{MnO}_{2}$ ” by a low temperature synthetic route [14].

Either reduction or substitution with larger ions causes the cell volume to expand, particularly in the a and $b$ directions [4]. In the series of $\mathrm{Na}_{\mathrm{x}} \mathrm{Ti}_{\mathrm{y}} \mathrm{Mn}_{1-\mathrm{y}} \mathrm{O}_{2}$ compounds made at $850^{\circ} \mathrm{C}$, the sodium content decreases slightly (and manganese oxidation state increases accordingly), but the cell volumes increase at higher substitution levels because of the larger size of the $\mathrm{Ti}^{4+}$ ions $\left(0.68 \AA\right.$ for $\mathrm{Ti}^{4+}$ vs. $0.60 \AA$ for $\left.\mathrm{Mn}^{4+}[15]\right)$.

Because the distribution of titanium is not perfectly uniform and the scattering coefficients of $\mathrm{Mn}$ and $\mathrm{Ti}$ are similar, precise site occupancies and atomic positions for the transition metals could not be obtained. From average bond lengths and site symmetry, however, it is clear that $\mathrm{Ti}^{4+}$ substitutes for $\mathrm{Mn}^{4+}$ in the $\mathrm{Mn} 1, \mathrm{Mn} 2$, and/or 
Mn3 sites in an essentially random fashion. It is not possible to rule out unequivocally Mn5 substitution in the more highly substituted compounds, but replacement of Mn in the Mn4 sites is unlikely because the square pyramidal coordination favors a Jahn-Teller ion. The difficulty in dissolving these materials and the lack of suitable reference compounds thwarted an accurate determination of their composition, but estimates were obtained using laser ablation/mass spectroscopy (Table 1).

Figure 4 shows XRD patterns of $\mathrm{Li}_{\mathrm{x}} \mathrm{Ti}_{\mathrm{y}} \mathrm{Mn}_{1-\mathrm{y}} \mathrm{O}_{2}$, the lithium-exchanged compounds, and Figure 5 shows a refinement typical of those from which the structural parameters listed in Table 3 were derived. In some cases, occupancies of lithium sites were higher than expected, implying the presence of small amounts of sodium, although none was detected by laser ablation/mass spectroscopy. The XRD experiment is extremely sensitive to traces of sodium, however, and is relatively insensitive to light elements such as lithium. The lithium content in $\mathrm{Li}_{x} \mathrm{Ti}_{y} \mathrm{Mn}_{1-\mathrm{y}} \mathrm{O}_{2}$ compounds could be estimated from the laser ablation/mass spectroscopy experiments (Table 1), but not from the Rietveld refinements. In all cases, $\mathrm{x}$ in $\mathrm{Li}_{\mathrm{x}} \mathrm{Ti}_{\mathrm{y}} \mathrm{Mn}_{1-\mathrm{y}} \mathrm{O}_{2}$ is slightly lower than $\mathrm{x}$ in $\mathrm{Na}_{x} \mathrm{Ti}_{\mathrm{y}} \mathrm{Mn}_{1-\mathrm{y}} \mathrm{O}_{2}$ determined from pattern refinements, indicating that oxidation takes place during the molten salt exchange. Because the free energies of formation of $\mathrm{Li}_{2} \mathrm{CO}_{3}, \mathrm{LiOH}$, and $\mathrm{Li}_{2} \mathrm{O}$ are lower than those of the corresponding sodium salts [15], lithiated compounds with the $\mathrm{Na}_{0.44} \mathrm{MnO}_{2}$ structure are more susceptible to air-oxidation than their sodium-containing counterparts.

The cell volumes of $\mathrm{Li}_{\mathrm{x}} \mathrm{Ti}_{\mathrm{y}} \mathrm{Mn}_{1-\mathrm{y}} \mathrm{O}_{2}$ compounds are considerably smaller than those of the analogous $\mathrm{Na}_{\mathrm{x}} \mathrm{Ti}_{\mathrm{y}} \mathrm{Mn}_{1-\mathrm{y}} \mathrm{O}_{2}$ compounds, due to the replacement of sodium ions with smaller lithium ions. All are larger than that of $\mathrm{Li}_{0.27} \mathrm{MnO}_{2}$ made from $\mathrm{Na}_{0.44} \mathrm{MnO}_{2}$ 
due to the replacement of some manganese with titanium. The unit cell size is influenced both by the titanium content and the average oxidation state of the manganese ions in this series.

\section{Electrochemical Characterization}

Freshly-assembled $\mathrm{Li} / \mathrm{P}(\mathrm{EO})_{8} \mathrm{LiTFSI} / \mathrm{Li}_{\mathrm{x}} \mathrm{Ti}_{\mathrm{y}} \mathrm{Mn}_{1-\mathrm{y}} \mathrm{O}_{2}$ cells heated to $85{ }^{\circ} \mathrm{C}$ have open-circuit potentials (OCPs) of 3.32 to $3.42 \mathrm{~V}$ except for those containing the $\mathrm{y}=0.11$ compound, which are slightly lower (3.25 to $3.3 \mathrm{~V}$ ) due to the greater lithium content. They are in the partially discharged state, and can either be charged or discharged initially. Stepped potential (ECPS) experiments were carried out to compare lithium insertion processes of $\mathrm{Li}_{\mathrm{x}} \mathrm{Ti}_{\mathrm{y}} \mathrm{Mn}_{1-\mathrm{y}} \mathrm{O}_{2}$ compounds to those of $\mathrm{Li}_{\mathrm{x}} \mathrm{MnO}_{2}$ with the $\mathrm{Na}_{0.44} \mathrm{MnO}_{2}$ structure. Differential capacity $(\Delta \mathrm{Q} / \Delta \mathrm{V})$ plots obtained during the first full cycle on cells containing $\mathrm{Li}_{\mathrm{x}} \mathrm{MnO}_{2}$ or $\mathrm{Li}_{\mathrm{x}} \mathrm{Ti}_{\mathrm{y}} \mathrm{Mn}_{1-\mathrm{y}} \mathrm{O}_{2}$ compounds prepared at $850^{\circ} \mathrm{C}$ are shown in Figures 6a and 6b-f, respectively.

Lithium insertion processes into $\mathrm{Li}_{\mathrm{x}} \mathrm{Ti}_{\mathrm{y}} \mathrm{Mn}_{1-\mathrm{y}} \mathrm{O}_{2}$ compounds are highly reversible, as they are with $\mathrm{Li}_{\mathrm{x}} \mathrm{MnO}_{2}$, but they differ in some important respects. In well-exchanged samples of the latter, two sets of sharp peaks appear at about 3.05 and $3.33 \mathrm{~V}$ vs. $\mathrm{Li}$ (additional features seen in this region in earlier $\Delta \mathrm{Q} / \Delta \mathrm{V}$ data $[2,4]$ indicate that a second, sodium-containing phase is present; i.e., the exchange process was incomplete). The peaks broaden considerably, and a new feature at about $2.9 \mathrm{~V}$ vs. Li appears and becomes relatively larger as $\mathrm{y}$ in $\mathrm{Li}_{\mathrm{x}} \mathrm{Ti}_{\mathrm{y}} \mathrm{Mn}_{1-\mathrm{y}} \mathrm{O}_{2}$ increases. In the case of the $\mathrm{Li}_{\mathrm{x}} \mathrm{Ti}_{0.22} \mathrm{Mn}_{0.78} \mathrm{O}_{2}$ material made from a sol-gel precursor (not shown), the major feature is a very broad peak at $3.1 \mathrm{~V}$, and much less capacity is seen at $3.3 \mathrm{~V}$ and $2.9 \mathrm{~V}$ than for $\mathrm{Li}_{\mathrm{x}} \mathrm{Ti}_{0.22} \mathrm{Mn}_{0.78} \mathrm{O}_{2}$ 
made from a conventional precursor. (A very small, sharp set of peaks at around $3.0 \mathrm{~V}$ could be assigned to the spinel contaminant in the sol-gel material).

It has been suggested that peaks in the $\Delta \mathrm{Q} / \Delta \mathrm{V}$ plots of $\mathrm{Li} / \mathrm{Li}_{x} \mathrm{MnO}_{2}$ cells are due to lithium ordering in the tunnels [2], but this seems somewhat unlikely given that several types of sites with differing symmetries are possible for these ions. A more plausible explanation is that selective reduction/oxidation of $\mathrm{Mn}$ in specific sites occurs with concomitant structural changes, resulting in distinct, highly reversible, phase transitions.

An XRD study of $\mathrm{Na}_{0.44} \mathrm{MnO}_{2}$ and its chemically exchanged, reduced, and oxidized derivatives [12] showed that $\mathrm{Mn}$ in the $\mathrm{Mn} 1$ site is in the +4 oxidation state in $\mathrm{Na}_{0.44} \mathrm{MnO}_{2}$ and $\mathrm{Li}_{0.27} \mathrm{MnO}_{2}$, but in the +3 oxidation state in $\mathrm{Li}_{0.62} \mathrm{MnO}_{2}$. Mn in the Mn5 site is in the +3 oxidation site in $\mathrm{Na}_{0.44} \mathrm{MnO}_{2}$ and $\mathrm{Li}_{0.62} \mathrm{MnO}_{2}$, but is in the +4 state in $\mathrm{Li}_{0.27} \mathrm{MnO}_{2}$. There are also significant differences in the Mn coordination spheres among these compounds, allowing the S-shaped tunnels to flex and the $\mathrm{MnO}_{5}$ square pyramids to hinge to accommodate varying amounts of lithium or sodium ions in the tunnels.

Although there is not yet enough experimental evidence to verify this, or to rule out other possibilities such as differing site energetics, the observations on the titaniumcontaining compounds are not inconsistent with this theory. The presence of electrochemically inert titanium on manganese sites in $\mathrm{Li}_{x} \mathrm{Ti}_{y} \mathrm{Mn}_{1-\mathrm{y}} \mathrm{O}_{2}$ compounds may cause different manganese ions to participate in the redox process, particularly if normally electroactive sites are partially or fully substituted. The broadening of features in the $\Delta \mathrm{Q} / \Delta \mathrm{V}$ plots of cells containing $\mathrm{Li}_{\mathrm{x}} \mathrm{Ti}_{\mathrm{y}} \mathrm{Mn}_{1-\mathrm{y}} \mathrm{O}_{2}$ compared to $\mathrm{Li}_{\mathrm{x}} \mathrm{MnO}_{2}$ may be due to the random and somewhat heterogeneous distribution of Ti, which is likely to complicate and attenuate the phase transitions. The differences in the $\Delta \mathrm{Q} / \Delta \mathrm{V}$ plots of cells containing 
$\mathrm{Li}_{\mathrm{x}} \mathrm{Ti}_{0.22} \mathrm{Mn}_{0.78} \mathrm{O}_{2}$ made from a sol-gel precursor also suggest that Ti substitution in these materials is very complex and dependent upon synthesis method.

Integration of the data in Figures 6a-f allows pseudo-open circuit potential (OCP) profiles to be obtained (Figure 7). That of $\mathrm{Li} / \mathrm{P}(\mathrm{EO})_{8} \mathrm{LiTFSI}_{\mathrm{Li}} \mathrm{LMnO}_{2}$ cells is gradually sloping between 3.5 and $2.5 \mathrm{~V}$, with two distinct plateaus corresponding to the peaks in the $\Delta \mathrm{Q} / \Delta \mathrm{V}$ plots. Slightly less than $100 \mathrm{mAh} / \mathrm{g}$ is delivered, corresponding to $\Delta \mathrm{x}$ in $\mathrm{Li}_{\mathrm{x}} \mathrm{MnO}_{2}$ of about 0.3 (from about $\mathrm{x}=0.3$ to $\mathrm{x}=0.6$ ). This is similar to that found for $\mathrm{Li}_{\mathrm{x}} \mathrm{Ti}_{\mathrm{y}} \mathrm{Mn}_{1-\mathrm{y}} \mathrm{O}_{2}$ compounds with $\mathrm{y}=0.11,0.33$, or 0.44 , although relatively more capacity is found at around $2.9 \mathrm{~V}$ and no plateaus are evident. OCP profiles of cells containing conventionally prepared $\mathrm{Li}_{x} \mathrm{Ti}_{0.22} \mathrm{Mn}_{0.78} \mathrm{O}_{2}$ show about $20 \%$ more capacity in this potential range, while those of cells containing the sol-gel derived $\mathrm{Li}_{\mathrm{x}} \mathrm{Ti}_{0.22} \mathrm{Mn}_{0.78} \mathrm{O}_{2}$ (not shown) or $\mathrm{Li}_{\mathrm{x}} \mathrm{Ti}_{0.55} \mathrm{Mn}_{0.45} \mathrm{O}_{2}$ display markedly less. Titanium increases the unit cell size, but is probably electrochemically inert in this potential range. Thus, these results represent a trade-off between the beneficial effects of increasing the unit cell size, which allows more of the lithium to be extracted, and losses represented by replacement of some electroactive Mn with inactive Ti.

Figure 8 shows galvanostatic discharges of $\mathrm{Li} / \mathrm{P}(\mathrm{EO}){ }_{8} \mathrm{LiTFSI} / \mathrm{Li}_{\mathrm{x}} \mathrm{Ti}_{0.22} \mathrm{Mn}_{0.78} \mathrm{O}_{2}$ (conventionally prepared) cells at $85{ }^{\circ} \mathrm{C}$. There is slightly less utilization than that predicted by the ECPS experiments, even at low rates (e.g., $0.1 \mathrm{~mA} / \mathrm{cm}^{2}$, corresponding to C/5 for the cell shown). It is still, however, somewhat higher than that found for optimized $\mathrm{Li}_{\mathrm{x}} \mathrm{MnO}_{2}$ electrodes in the same cell configuration. This advantage disappears when cells containing $\mathrm{Li}_{x} \mathrm{Ti}_{0.22} \mathrm{Mn}_{0.78} \mathrm{O}_{2}$ are discharged at higher current densities; utilization for the cell in Figure 9 at $0.5 \mathrm{~mA} / \mathrm{cm}^{2}$, is equal to that found for 
$\mathrm{Li} / \mathrm{P}(\mathrm{EO})_{8} \mathrm{LiTFSI} / \mathrm{Li}_{\mathrm{x}} \mathrm{MnO}_{2}$ cells at the same current density [1]. The difference is even more marked when the performance of liquid electrolyte cells at room temperature is compared. Thus, the rate capability of this sample of $\mathrm{Li}_{x} \mathrm{Ti}_{0.22} \mathrm{Mn}_{0.78} \mathrm{O}_{2}$ appears to be inferior to that of the $\mathrm{Li}_{x} \mathrm{MnO}_{2}$ described in Ref. 1. An examination of relative diffusion coefficients obtained by analysis of the current vs. time data during the stepped potential experiments confirms this. The rate capability of $\mathrm{Li}_{\mathrm{x}} \mathrm{Ti}_{0.22} \mathrm{Mn}_{0.78} \mathrm{O}_{2}$ also seems to be somewhat inferior to that of other $\mathrm{Li}_{\mathrm{x}} \mathrm{Ti}_{\mathrm{y}} \mathrm{Mn}_{1-\mathrm{y}} \mathrm{O}_{2}$ electrodes, which are utilized fully in polymer cells at $0.1 \mathrm{~mA} / \mathrm{cm}^{2}(\mathrm{C} / 3-\mathrm{C} / 5$ rate $)$.

The rate capability and utilization of $\mathrm{Li}_{\mathrm{x}} \mathrm{MnO}_{2}$ electrodes is strongly dependent upon synthesis method and processing details [1]. The crystals are needle-like with the tunnels, along which lithium ion diffusion occurs, aligned parallel to the long axis. Glycine-nitrate combustion synthesis and attrition-milling conventionally prepared powders results in shorter needles, which give better electrode performance. SEM images of $\mathrm{Li}_{\mathrm{x}} \mathrm{Ti}_{\mathrm{y}} \mathrm{Mn}_{1-\mathrm{y}} \mathrm{O}_{2}$ powders indicate, however, that most of the particles are nearly equiaxial rather than needle-like. Attrition-milling $\mathrm{Li}_{\mathrm{x}} \mathrm{Ti}_{0.22} \mathrm{Mn}_{0.78} \mathrm{O}_{2}$ powders did not result in substantially smaller particles, and utilization in polymer cells actually decreased for ground materials. The titanium-substituted manganese oxides are exceptionally hard and difficult to grind; contamination from the zirconia balls used during attrition milling may have resulted in low utilization, thus compromising the performance of the ground $\mathrm{Li}_{\mathrm{x}} \mathrm{Ti}_{0.22} \mathrm{Mn}_{0.78} \mathrm{O}_{2}$.

Cycling data for $\mathrm{Li} / \mathrm{P}(\mathrm{EO})_{8} \mathrm{LiTFSI} / \mathrm{Li}_{\mathrm{x}} \mathrm{Ti}_{0.22} \mathrm{Mn}_{0.78} \mathrm{O}_{2}$ and $\mathrm{Li}_{\mathrm{x}} \mathrm{Ti}_{0.33} \mathrm{Mn}_{0.67} \mathrm{O}_{2}$ cells at $85^{\circ} \mathrm{C}$ are shown in Figures 9 and 10. Li/P(EO) ${ }_{8} \mathrm{LiTFSI}_{/} / \mathrm{Li}_{\mathrm{x}} \mathrm{Ti}_{0.22} \mathrm{Mn}_{0.78} \mathrm{O}_{2}$ cells discharged at $0.5 \mathrm{~mA} / \mathrm{cm}^{2}$ have slightly lower capacity and fade more quickly than those discharged 
at $0.1 \mathrm{~mA} / \mathrm{cm}^{2}$ between 2.5 and $3.6 \mathrm{~V}$ (a loss of $0.06 \%$ per cycle for the former vs. $0.04 \%$ for the latter). In comparison, polymer cells containing optimized $\mathrm{Li}_{x} \mathrm{MnO}_{2}$ as the cathode can be discharged repeatedly at $0.5 \mathrm{~mA} / \mathrm{cm}^{2}$ with a loss of only $0.02 \%$ per cycle under the same conditions. Decreasing the lower voltage limit from 2.5 to $2.4 \mathrm{~V}$ results in full utilization for cells discharged at $0.1 \mathrm{~mA} / \mathrm{cm}^{2}$, but causes faster fading (an average loss of $0.17 \%$ per cycle). The cycling behavior of $\mathrm{Li} / \mathrm{P}(\mathrm{EO})_{8} \mathrm{LiTFSI} / \mathrm{Li}_{\mathrm{x}} \mathrm{Ti}_{0.33} \mathrm{Mn}_{0.67} \mathrm{O}_{2}$ cells is also sensitive to the lower voltage limit used; those cycled between 2.5 and $3.6 \mathrm{~V}$ lost capacity at a rate of less than $0.03 \%$ per cycle, compared to $0.05 \%$ when the voltage limit was lowered to $2.4 \mathrm{~V}$ and $0.09 \%$ when it was dropped to $2.2 \mathrm{~V}$. Although there is a slight improvement in capacity even for $\mathrm{Li}_{\mathrm{x}} \mathrm{Ti}_{0.33} \mathrm{Mn}_{0.67} \mathrm{O}_{2}$ electrodes when wider voltage limits are used, the advantage is offset after about 100 cycles due to the faster capacity loss. For EV applications, 1000 cycles to $80 \%$ utilization or better is desired for battery systems, requiring that single cells lose less than $0.02 \%$ per cycle, on average.

At present, the only known mechanism for capacity loss in lithium cells directly attributable to electrodes with the $\mathrm{Na}_{0.44} \mathrm{MnO}_{2}$ structure involves a very slow transition to an unknown phase with inferior electrochemical properties during deep discharge [4]. The phase transition is manifested as a large, broad, and irreversible peak below $2.5 \mathrm{~V}$ in $\Delta \mathrm{Q} / \Delta \mathrm{V}$ plots from ECPS experiments performed on cells stepped to low voltages for tens or hundreds of hours. In galvanostatic experiments, there is a pronounced hysteresis in the shapes of cycling curves below $2.5 \mathrm{~V}$, which can be repeated over many subsequent deep discharges until the conversion is complete. These features are seen upon deep discharge of $\mathrm{Li} / \mathrm{P}(\mathrm{EO})_{8} \mathrm{LiTFSI} / \mathrm{Li}_{\mathrm{x}} \mathrm{Ti}_{\mathrm{y}} \mathrm{Mn}_{1-\mathrm{y}} \mathrm{O}_{2}$ cells as well, indicating a similar phenomenon occurs in the titanium-substituted materials. It is, therefore, likely that the accelerated losses seen 
in $\mathrm{Li} / \mathrm{P}(\mathrm{EO})_{8} \mathrm{LiTFSI} / \mathrm{Li}_{\mathrm{x}} \mathrm{Ti}_{0.22} \mathrm{Mn}_{0.78} \mathrm{O}_{2}$ and $\mathrm{Li}_{\mathrm{x}} \mathrm{Ti}_{0.33} \mathrm{Mn}_{0.67} \mathrm{O}_{2}$ cells discharged repeatedly below 2.5 V are due to the same extremely slow irreversible phase transition. Under nonequilibrium conditions (e.g., high rate discharges), this can also occur even if cells are never discharged below $2.5 \mathrm{~V}$, particularly if lithium insertion is sluggish, as appears to be the case with $\mathrm{Li}_{x} \mathrm{Ti}_{0.22} \mathrm{Mn}_{0.78} \mathrm{O}_{2}$. It has been shown in the case of $\mathrm{Li}_{\mathrm{x}} \mathrm{MnO}_{2}$ with the $\mathrm{Na}_{0.44} \mathrm{MnO}_{2}$ structure that engineering more favorable particle morphology to shorten diffusion path lengths can ameliorate capacity fading associated with high rate discharge. Unfortunately, attempts to do so with the titanium-doped materials by grinding or soft chemistry synthesis (e.g., sol-gel) have resulted in inferior performance due to contamination or different substitution patterns of the Ti.

These results suggest that there is no intrinsic advantage to substituting these manganese oxides with titanium at present. While somewhat increased capacity is obtained when $22 \%$ of the manganese is replaced with titanium, it appears to come at the expense of rate capability and cycle life. The random distribution of titanium throughout these materials makes it difficult to produce homogeneous powders with small particle dimensions to offset the sluggishness, as can be done with unsubstituted $\mathrm{Li}_{x} \mathrm{MnO}_{2}$. However, this study does show that it is possible to modify the discharge profiles by chemical modification of manganese oxides with the $\mathrm{Na}_{0.44} \mathrm{MnO}_{2}$ structure, and offers some insight into how this influences the electrochemical characteristics. The capacity between set voltage limits is determined not only by the size of the unit cell in manganese oxides with the $\mathrm{Na}_{0.44} \mathrm{MnO}_{2}$ structure, but also by the redox activity of the substituting ion and the specific sites where manganese is substituted. The effect of chemical modification upon the particle morphology and the rate of lithium ion diffusion are also factors that 
must be considered. At present, we are studying other substituted manganese oxides with the $\mathrm{Na}_{0.44} \mathrm{MnO}_{2}$ structure in order to understand these better. This should ultimately lead to robust materials with increased energy density as well as the excellent cyclability and high rate capability exhibited by optimized $\mathrm{Li}_{x} \mathrm{MnO}_{2}$ materials.

\section{Conclusions}

A series of titanium-substituted manganese oxides, $\mathrm{Li}_{\mathrm{x}} \mathrm{Ti}_{\mathrm{y}} \mathrm{Mn}_{1-\mathrm{y}} \mathrm{O}_{2}(\mathrm{y}=0.11,0.22$, $0.33,0.44$, and 0.55 ) with the $\mathrm{Na}_{0.44} \mathrm{MnO}_{2}$ structure was prepared and characterized. Titanium replaces manganese in a random and somewhat heterogeneous fashion, rather than on specific manganese sites in these materials. There is a trade-off between the beneficial effect upon capacity of increasing the unit cell size and the detrimental effect of replacing electrochemically active manganese ions with inert, but larger, titanium ions. Best results are obtained for $\mathrm{Li}_{\mathrm{x}} \mathrm{Ti}_{0.22} \mathrm{Mn}_{0.78} \mathrm{O}_{2}$, which delivers about $10-20 \%$ more capacity than $\mathrm{Li}_{\mathrm{x}} \mathrm{MnO}_{2}$ in lithium cells discharged at low rates or subjected to ECPS experiments. While it is more difficult to engineer the $\mathrm{Li}_{\mathrm{x}} \mathrm{Ti}_{\mathrm{y}} \mathrm{Mn}_{1-\mathrm{y}} \mathrm{O}_{2}$ materials for optimum electrochemical performance than for $\mathrm{Li}_{\mathrm{X}} \mathrm{MnO}_{2}$, it is still possible to discharge cells repeatedly with capacity fade rates of less than $0.03 \%$ per cycle.

\section{Acknowledgments}

This work was supported by the Assistant Secretary for Energy Efficiency and Renewable

Energy, Office of Transportation Technologies, Office of Advanced Automotive Technologies of the U.S. Department of Energy under Contract No. DE-AC0376SF00098. KTH would like to thank the Korea Science and Engineering Foundation (KOSEF) for funding. 


\section{References}

1. M. M. Doeff, A. Anapolsky, L. Edman, T. J. Richardson, and L. C. De Jonghe, J. Electrochem. Soc. 148 (2001) A230.

2. A. R. Armstrong, H. Huang, R. A. Jennings, and P. G. Bruce, J. Mater. Chem. 8, (1998) 255.

3. A. Blyr, C. Sigala, G. Amatucci, D. Guyomard, Y. Chabre, and J. M. Tarascon, J. Electrochem. Soc. 145 (1998) 194.

4. M. M. Doeff, T. J. Richardson, and L. Kepley, J. Electrochem. Soc. 143 (1996) 2507.

5. T. J. Richardson and P. N. Ross, $194^{\text {th }}$ Electrochem Society Meeting, Boston, MA 1998, Vol. 98-2, Abstract No. 130.

6. M. M. Doeff, L. Ding, and L.C. De Jonghe, Mat. Res. Soc. Proc. 393 (1995) 107.

7. M. M. Doeff, M. Y. Peng, Y. Ma, and L.C. De Jonghe, J. Electrochem. Soc. 141 (1994) L145.

8. M. M. Doeff, T. J. Richardson, and L. C. De Jonghe, The Second Hawaii Battery Conference (HBC99), Waikoloa, HI, 1999, Abstracts, p. 340.

9. J.-P. Parant, R. Olazcuaga, M. DeValette, C. Fouassier, and P. Hagenmuller, J. Solid State Chem. 3 (1971) 1.

10. G. T. Kim and Y. Shim, Kor. J. of Mat. Res., 7 (1997) 529.

11. S. Mountford, unpublished results. 
12. T. J. Richardson, P. N. Ross, Jr., and M. M. Doeff, Proc. Electrochem. Soc. 98-16 (1999) 229.

13. W.G. Mumme, Acta Crystallogr., B24 (1968) 1114.

14. Y. U. Jeong and A. Manthiram, Electrochem. and Solid-State Lett., 2 (1999) 421.

15. Handbook of Chemistry and Physics, R. C. Weast, Editor, $68^{\text {th }}$ ed., CRC Press, Inc., Boca Raton, FL (1987-1988). 
Table 1. Laser ablation/mass spectroscopy ${ }^{a}$ results on $\mathrm{Na}_{\mathrm{x}} \mathrm{Ti}_{\mathrm{y}} \mathrm{Mn}_{1-\mathrm{y}} \mathrm{O}_{2}{ }^{\mathrm{b}}$ and

\section{$\mathrm{Li}_{\mathrm{x}} \mathrm{Ti}_{\mathrm{y}} \mathrm{Mn}_{1-\mathrm{y}} \mathrm{O}_{2}{ }^{\mathrm{c}}$ compounds}

\begin{tabular}{|c|c|c|c|c|}
\hline Nominal composition, & $\mathrm{y}$ & $\begin{array}{c}\text { Nominal composition, } \\
\mathrm{y} \text { in } \mathrm{Na}_{\mathrm{x}} \mathrm{Ti}_{\mathrm{y}} \mathrm{Mn}_{1-\mathrm{y}} \mathrm{O}_{2}\end{array}$ & $\begin{array}{c}\mathrm{y} \\
\text { (estimated) }\end{array}$ & $\mathrm{y}$ in $\mathrm{Li}_{\mathrm{x}} \mathrm{Ti}_{\mathrm{y}} \mathrm{Mn}_{1-\mathrm{y}} \mathrm{O}_{2}$ \\
\hline 0.11 & 0.14 & 0.11 & 0.11 & 0.46 \\
\hline 0.22 & 0.26 & 0.22 & 0.26 & 0.35 \\
\hline 0.33 & 0.35 & 0.33 & 0.44 & 0.22 \\
\hline 0.44 & 0.49 & 0.44 & 0.47 & 0.35 \\
\hline
\end{tabular}
a) Obtained using samples of $\mathrm{MnO}_{2}$ or $\mathrm{LiMn}_{2} \mathrm{O}_{4}$ of known compositions as references.
b) Synthesized at $850^{\circ} \mathrm{C}$.
c) prepared by molten salt exchange of $\mathrm{Na}_{\mathrm{x}} \mathrm{Ti}_{\mathrm{y}} \mathrm{Mn}_{1-\mathrm{y}} \mathrm{O}_{2}$ compounds prepared at $850^{\circ} \mathrm{C}$. 
Table 2. Structural parameters and sodium contents of $\mathrm{Na}_{\mathrm{x}} \mathrm{Ti}_{\mathrm{y}} \mathrm{Mn}_{1-\mathrm{y}} \mathrm{O}_{2}$ phases (space group Pbam) from Rietveld refinements

\begin{tabular}{|c|c|c|c|c|c|}
\hline Nominal & \multicolumn{3}{|c|}{ Unit cell parameters $(\AA)$} & Cell Volume & $\mathrm{x}$ (found) \\
\hline Composition $^{\mathrm{a}}$ & $\mathrm{a}$ & b & C & $\left(\AA^{3}\right)$ & \\
\hline $\mathrm{Na}_{\mathrm{X}} \mathrm{MnO}_{2}^{\mathrm{b}}$ & 9.089 & 26.488 & 2.826 & 680 & 0.47 \\
\hline $\mathrm{Na}_{\mathrm{x}} \mathrm{Ti}_{0.11} \mathrm{Mn}_{0.89} \mathrm{O}_{2}$ & 9.135 & 26.478 & 2.839 & 686.6 & 0.5 \\
\hline $\mathrm{Na}_{\mathrm{x}} \mathrm{Ti}_{0.22} \mathrm{Mn}_{0.78} \mathrm{O}_{2}$ & 9.194 & 26.519 & 2.858 & 696.8 & 0.49 \\
\hline $\mathrm{Na}_{\mathrm{x}} \mathrm{Ti}_{0.22} \mathrm{Mn}_{0.78} \mathrm{O}_{2}{ }^{\mathrm{C}}$ & & & & & 0.33 \\
\hline $\mathrm{Na}_{\mathrm{x}} \mathrm{Ti}_{0.33} \mathrm{Mn}_{0.67} \mathrm{O}_{2}$ & 9.212 & 26.499 & 2.868 & 700.1 & 0.42 \\
\hline $\mathrm{Na}_{\mathrm{x}} \mathrm{Ti}_{0.44} \mathrm{Mn}_{0.56} \mathrm{O}_{2}$ & 9.214 & 26.501 & 2.874 & 701.7 & 0.35 \\
\hline $\mathrm{Na}_{\mathrm{x}} \mathrm{Ti}_{0.55} \mathrm{Mn}_{0.45} \mathrm{O}_{2}$ & 9.255 & 26.512 & 2.884 & 707.7 & \\
\hline
\end{tabular}

a) All materials prepared by conventional solid state synthesis at $850{ }^{\circ} \mathrm{C}$, except where otherwise noted.

b) from reference 4 .

c) Material prepared at $1000^{\circ} \mathrm{C}$. 
Table 3. Structural parameters of $\mathrm{Li}_{\mathrm{x}} \mathrm{Ti}_{\mathrm{y}} \mathrm{Mn}_{1-\mathrm{y}} \mathrm{O}_{2}$ phases (space group Pbam) from Rietveld refinements.

\begin{tabular}{|c|c|c|c|c|c|}
\hline Nominal & \multicolumn{3}{|c|}{ Unit cell parameters $(\AA)$} & Cell Volume & Average $\quad \mathrm{Mn}$ \\
\hline Composition $^{\mathrm{a}}$ & $\mathrm{a}$ & $\mathrm{b}$ & C & $\left(\AA^{3}\right)$ & oxidation state $^{\mathrm{c}}$ \\
\hline $\mathrm{Li}_{0.27} \mathrm{MnO}_{2}^{\mathrm{b}}$ & 8.917 & 24.09 & 2.83 & 608 & 3.73 \\
\hline $\mathrm{Li}_{\mathrm{x}} \mathrm{Ti}_{0.11} \mathrm{Mn}_{0.89} \mathrm{O}_{2}$ & 8.932 & 25.318 & 2.841 & 642.4 & 3.48 \\
\hline $\mathrm{Li}_{\mathrm{X}} \mathrm{Ti}_{0.22} \mathrm{Mn}_{0.78} \mathrm{O}_{2}$ & 8.964 & 24.869 & 2.854 & 636.2 & 3.55 \\
\hline $\mathrm{Li}_{\mathrm{x}} \mathrm{Ti}_{0.33} \mathrm{Mn}_{0.67} \mathrm{O}_{2}$ & 8.985 & 24.663 & 2.866 & 635.1 & 3.67 \\
\hline $\mathrm{Li}_{\mathrm{X}} \mathrm{Ti}_{0.44} \mathrm{Mn}_{0.56} \mathrm{O}_{2}$ & 9.016 & 24.719 & 2.875 & 640.7 & 3.38 \\
\hline $\mathrm{Li}_{\mathrm{X}} \mathrm{Ti}_{0.55} \mathrm{Mn}_{0.45} \mathrm{O}_{2}$ & 8.949 & 24.458 & 2.862 & 626.5 & \\
\hline
\end{tabular}

a) Materials prepared by molten salt ion exchange from $\mathrm{Na}_{\mathrm{x}} \mathrm{Ti}_{\mathrm{y}} \mathrm{Mn}_{1-\mathrm{y}} \mathrm{O}_{2}$ compounds made at $850{ }^{\circ} \mathrm{C}$.

b) From reference 4.

c) calculated using Li contents from laser ablation/mass spectroscopy results listed in Table 1. 


\section{Figure Captions}

1) Structure of $\mathrm{Na}_{0.44} \mathrm{MnO}_{2}$, looking down the c-axis. Spheres represent sodium ions or sites for sodium ions and are labeled. Sites for $\mathrm{Mn}$ ions located in $\mathrm{MnO}_{6}$ octahedra and $\mathrm{MnO}_{5}$ square pyramids are also labeled.

2) X-ray diffraction patterns of $\mathrm{Na}_{\mathrm{x}} \mathrm{Ti}_{\mathrm{y}} \mathrm{Mn}_{1-\mathrm{y}} \mathrm{O}_{2}$ compounds prepared at $850^{\circ} \mathrm{C}$, arranged in order of increasing titanium content from bottom to top. The bottom-most pattern is that of $\mathrm{Na}_{0.44} \mathrm{MnO}_{2}$, included for purposes of comparison.

3) X-ray diffraction pattern of $\mathrm{Na}_{0.35} \mathrm{Mn}_{0.55} \mathrm{Ti}_{0.44} \mathrm{O}_{2}$. Data points are represented by crosses, refined pattern and residual (offset) by solid lines.

4) $\mathrm{X}$-ray diffraction patterns of $\mathrm{Li}_{\mathrm{x}} \mathrm{Ti}_{\mathrm{y}} \mathrm{Mn}_{1-\mathrm{y}} \mathrm{O}_{2}$ compounds prepared by ion-exchange of $\mathrm{Na}_{\mathrm{x}} \mathrm{Ti}_{\mathrm{y}} \mathrm{Mn}_{1-\mathrm{y}} \mathrm{O}_{2}$ samples made at $850^{\circ} \mathrm{C}$, arranged in order of increasing titanium content from bottom to top. The bottom-most pattern is that of $\mathrm{Li}_{0.27} \mathrm{MnO}_{2}$ made from $\mathrm{Na}_{0.44} \mathrm{MnO}_{2}$, included for purposes of comparison.

5) X-ray diffraction pattern of $\mathrm{Li}_{x} \mathrm{Mn}_{0.55} \mathrm{Ti}_{0.44} \mathrm{O}_{2}$. Data points are represented by crosses, refined pattern and residual (offset) by solid lines. 
6) Differential capacity vs. potential (first full ECPS cycle) for $\mathrm{Li} / \mathrm{P}(\mathrm{EO})_{8} \mathrm{LiTFSI}_{\mathrm{Li}} \mathrm{MnO}_{2}$ and $\mathrm{Li} / \mathrm{P}(\mathrm{EO})_{8} \mathrm{LiTFSI}_{\mathrm{Li}} \mathrm{Li}_{\mathrm{x}} \mathrm{Ti}_{\mathrm{y}} \mathrm{Mn}_{1-\mathrm{y}} \mathrm{O}_{2}$ cells obtained from ECPS experiments at $85^{\circ} \mathrm{C}$ : a) $\mathrm{y}=0\left(\mathrm{Li}_{\mathrm{x}} \mathrm{MnO}_{2}\right.$, from reference 1) , b) y $=0.11$, c) y $=$ 0.22 , d) $y=0.33$, e) $y=0.44, f) y=0.55$. Titanium-containing compounds were made by exchanging materials conventionally prepared at $850^{\circ} \mathrm{C} . \mathrm{Li}_{\mathrm{x}} \mathrm{MnO}_{2}$ was made by exchanging a precursor synthesized by a glycine-nitrate combustion process.

7) Pseudo-open circuit potential profiles for $\mathrm{Li} / \mathrm{P}(\mathrm{EO})_{8} \mathrm{LiTFSI} / \mathrm{Li}_{\mathrm{x}} \mathrm{Ti}_{\mathrm{y}} \mathrm{Mn}_{1-\mathrm{y}} \mathrm{O}_{2}$ and $\mathrm{Li} / \mathrm{P}(\mathrm{EO})_{8} \mathrm{LiTFSI} / \mathrm{Li}_{\mathrm{x}} \mathrm{MnO}_{2}$ cells at $85^{\circ} \mathrm{C}$, derived by integrating the data shown in Figure 6: $y=0\left(\mathrm{Li}_{\mathrm{x}} \mathrm{MnO}_{2},-\right), \mathrm{y}=0.11(\mathrm{x}), \mathrm{y}=0.22(\Delta), \mathrm{y}=0.33(\mathrm{O}), \mathrm{y}=0.44(\square)$ and $\mathrm{y}=0.55$ (+).

8) Galvanostatic discharges of $\mathrm{Li} / \mathrm{P}(\mathrm{EO}){ }_{8} \mathrm{LiTFSI} / \mathrm{Li}_{\mathrm{x}} \mathrm{Ti}_{0.22} \mathrm{Mn}_{0.78} \mathrm{O}_{2}$ cells at ${ }^{\circ} 5^{\circ} \mathrm{C}: 0.1$ $\mathrm{mA} / \mathrm{cm}^{2}(-), 0.2 \mathrm{~mA} / \mathrm{cm}^{2}(---)$, and $0.5 \mathrm{~mA} / \mathrm{cm}^{2}(\cdots \cdot \cdots)$.

9) Cycling data for $\mathrm{Li} / \mathrm{P}(\mathrm{EO})_{8} \mathrm{LiTFSI} / \mathrm{Li}_{\mathrm{x}} \mathrm{Ti}_{0.22} \mathrm{Mn}_{0.78} \mathrm{O}_{2}$ cells at $85^{\circ} \mathrm{C}$, discharged at 0.1 $\mathrm{mA} / \mathrm{cm}^{2}$ between 3.6 and $2.5 \mathrm{~V}(\mathrm{x}), 0.1 \mathrm{~mA} / \mathrm{cm}^{2}$ between 3.6 and $2.4 \mathrm{~V}(\lambda)$, and 0.5 $\mathrm{mA} / \mathrm{cm}^{2}$ between 3.6 and $2.5 \mathrm{~V}(\square)$.

10) Cycling data for $\mathrm{Li} / \mathrm{P}(\mathrm{EO}){ }_{8} \mathrm{LiTFSI} / \mathrm{Li}_{\mathrm{x}} \mathrm{Ti}_{0.33} \mathrm{Mn}_{0.67} \mathrm{O}_{2}$ cells at $85{ }^{\circ} \mathrm{C}$, discharged at 0.1 $\mathrm{mA} / \mathrm{cm}^{2}$ between 3.6 and $2.5 \mathrm{~V}(\mathrm{x}), 3.6$ and $2.4 \mathrm{~V}(\lambda)$, and 3.6 and $2.2 \mathrm{~V}(\square)$. 


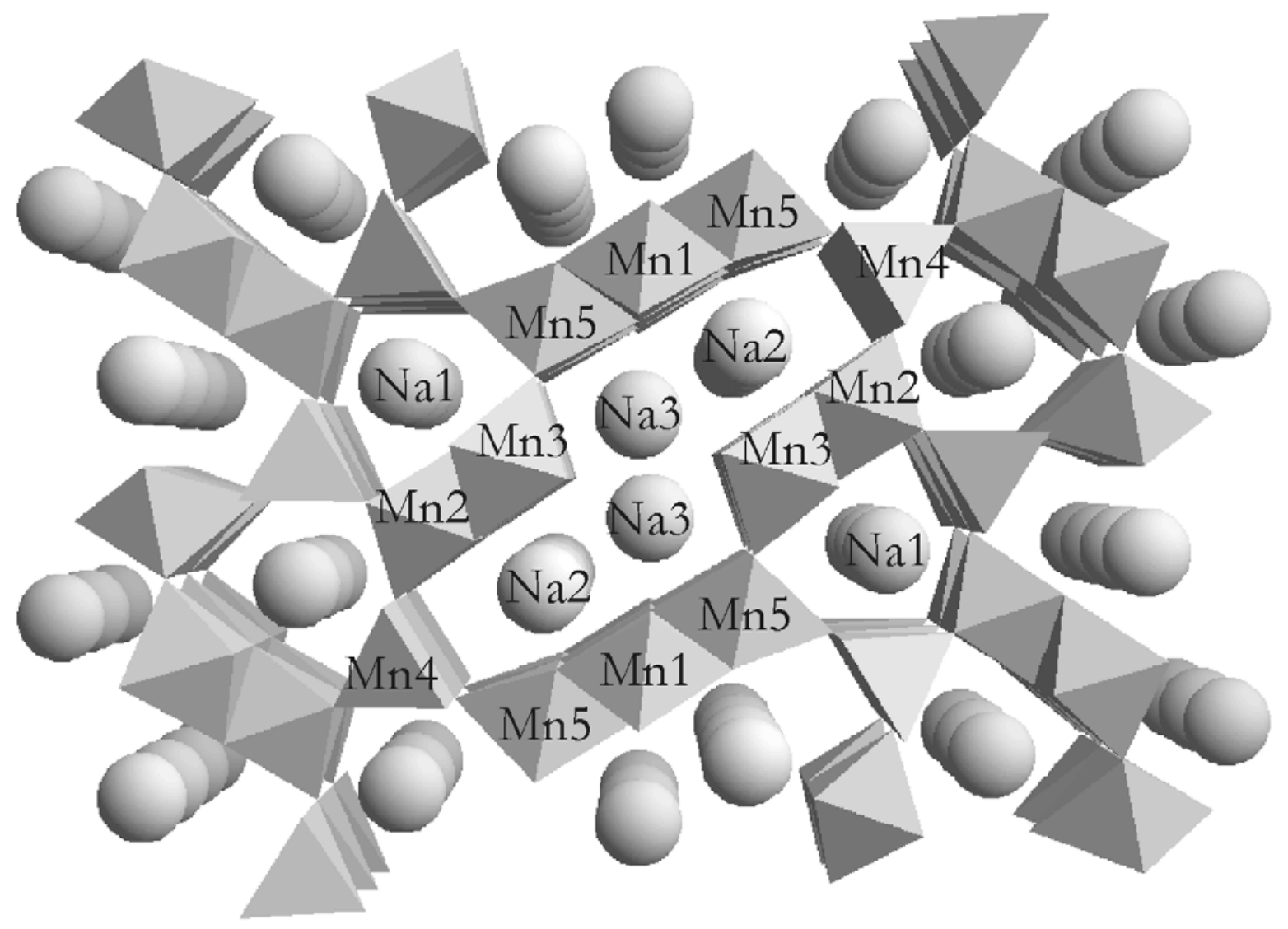

Figure 1 


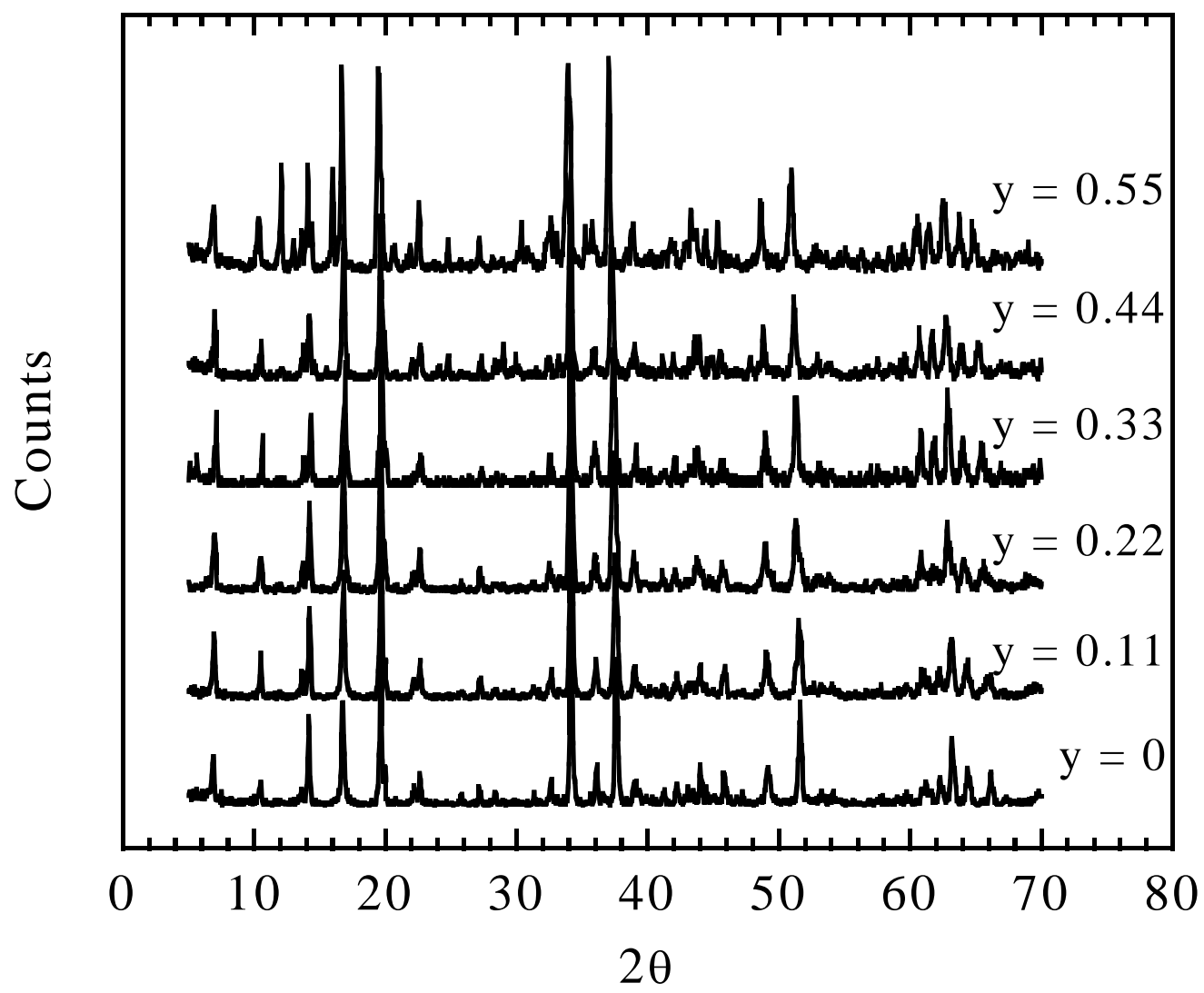

Figure 2 


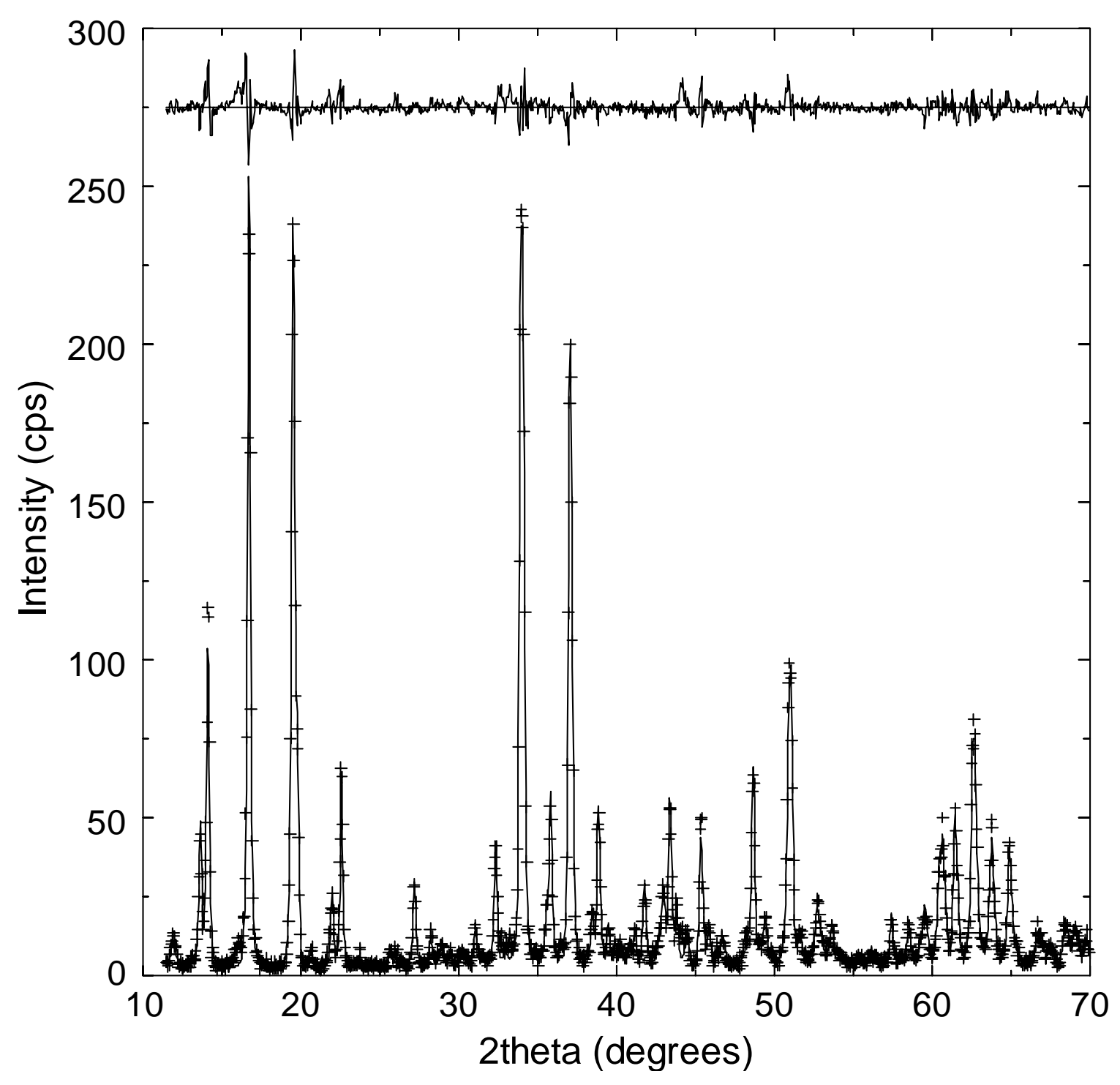

Figure 3 


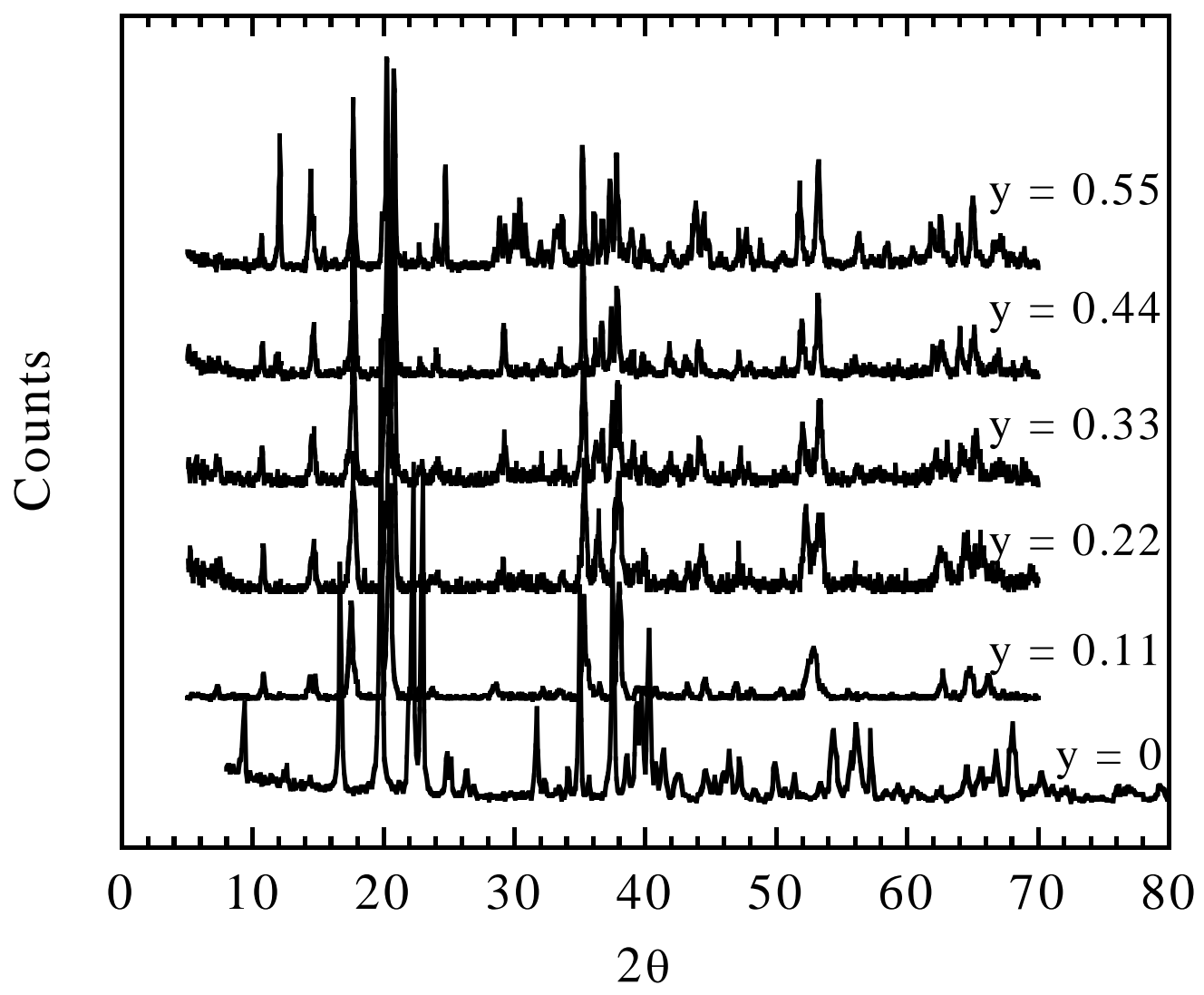

Figure 4 


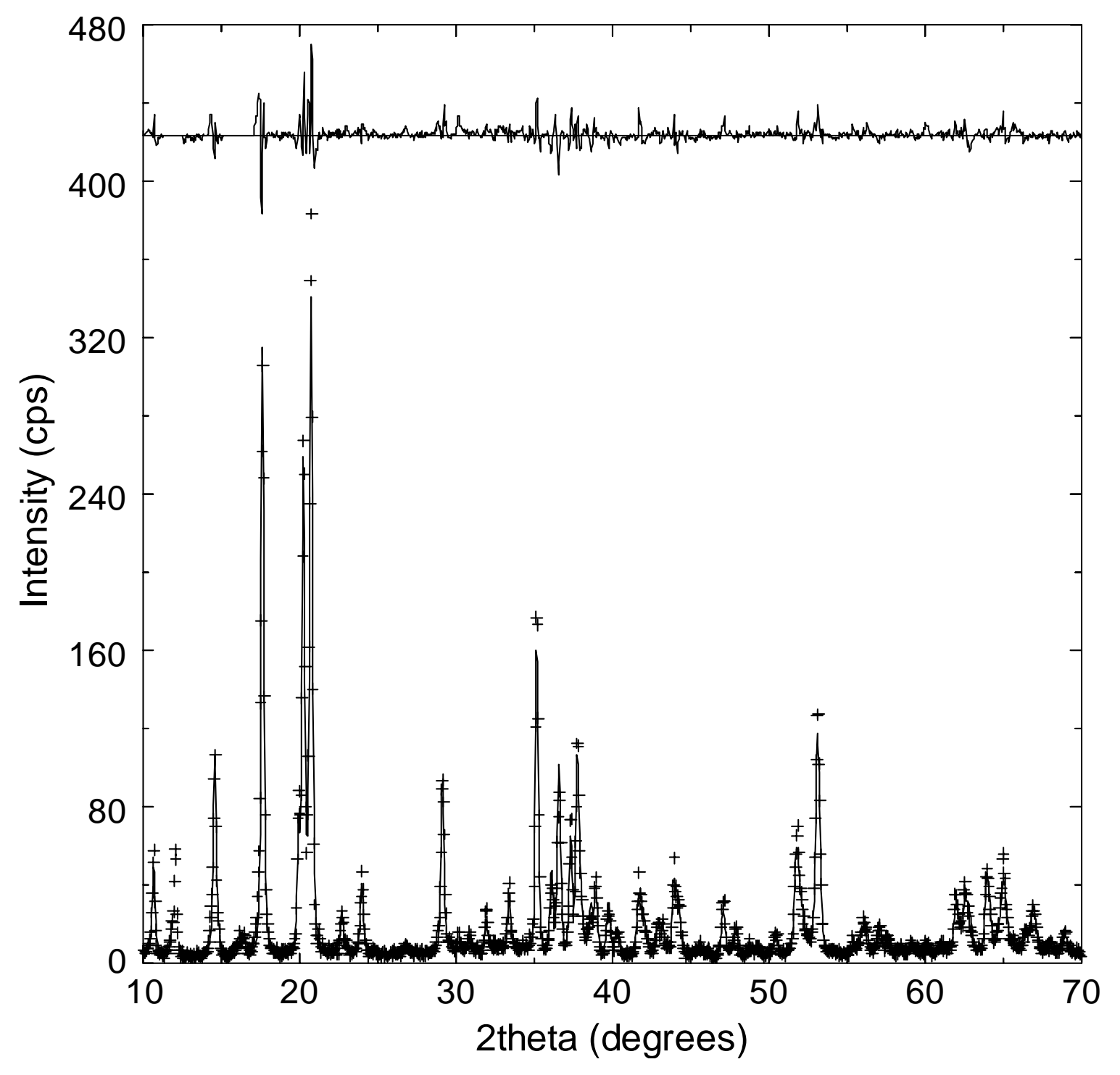

Figure 5 

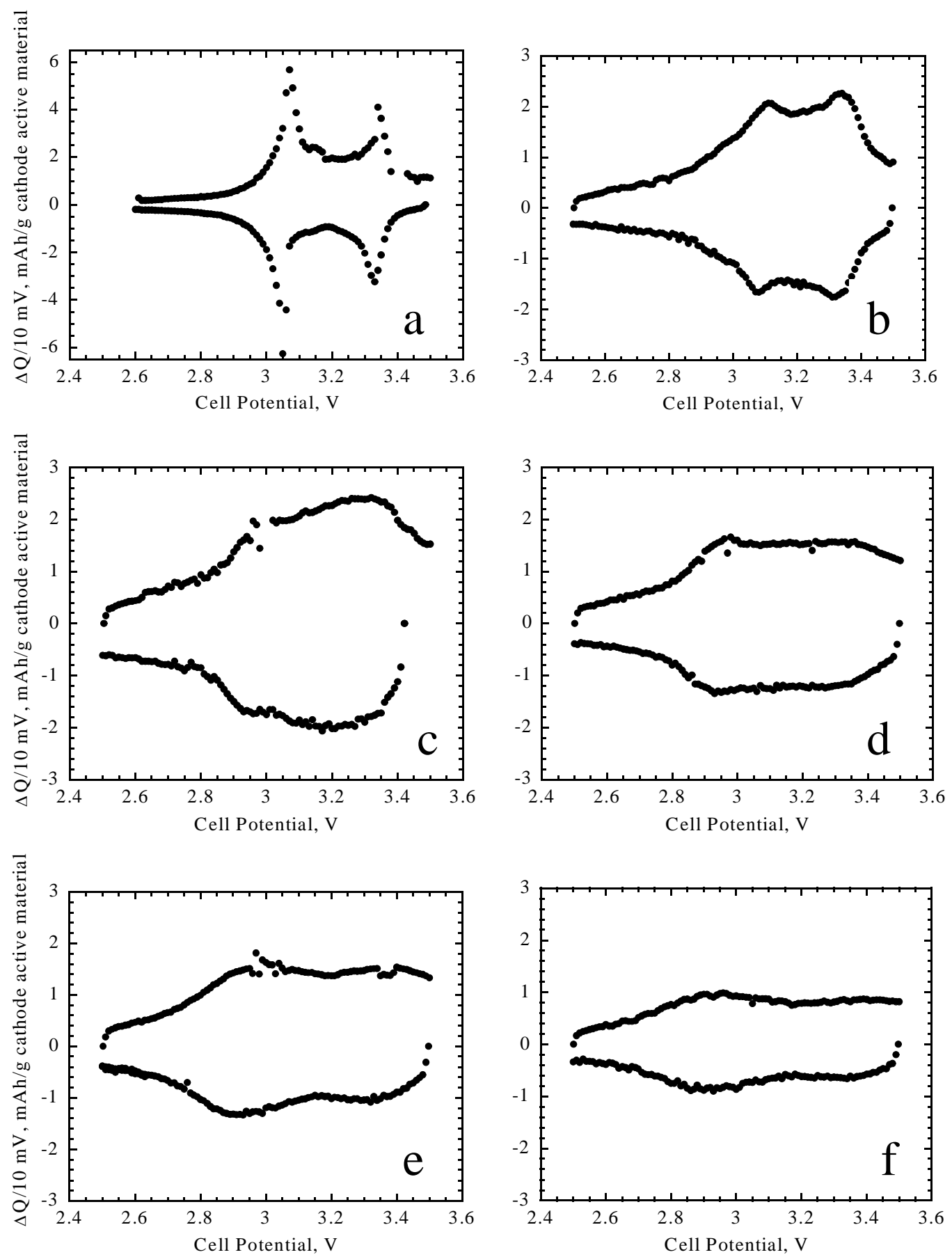

Figure 6 


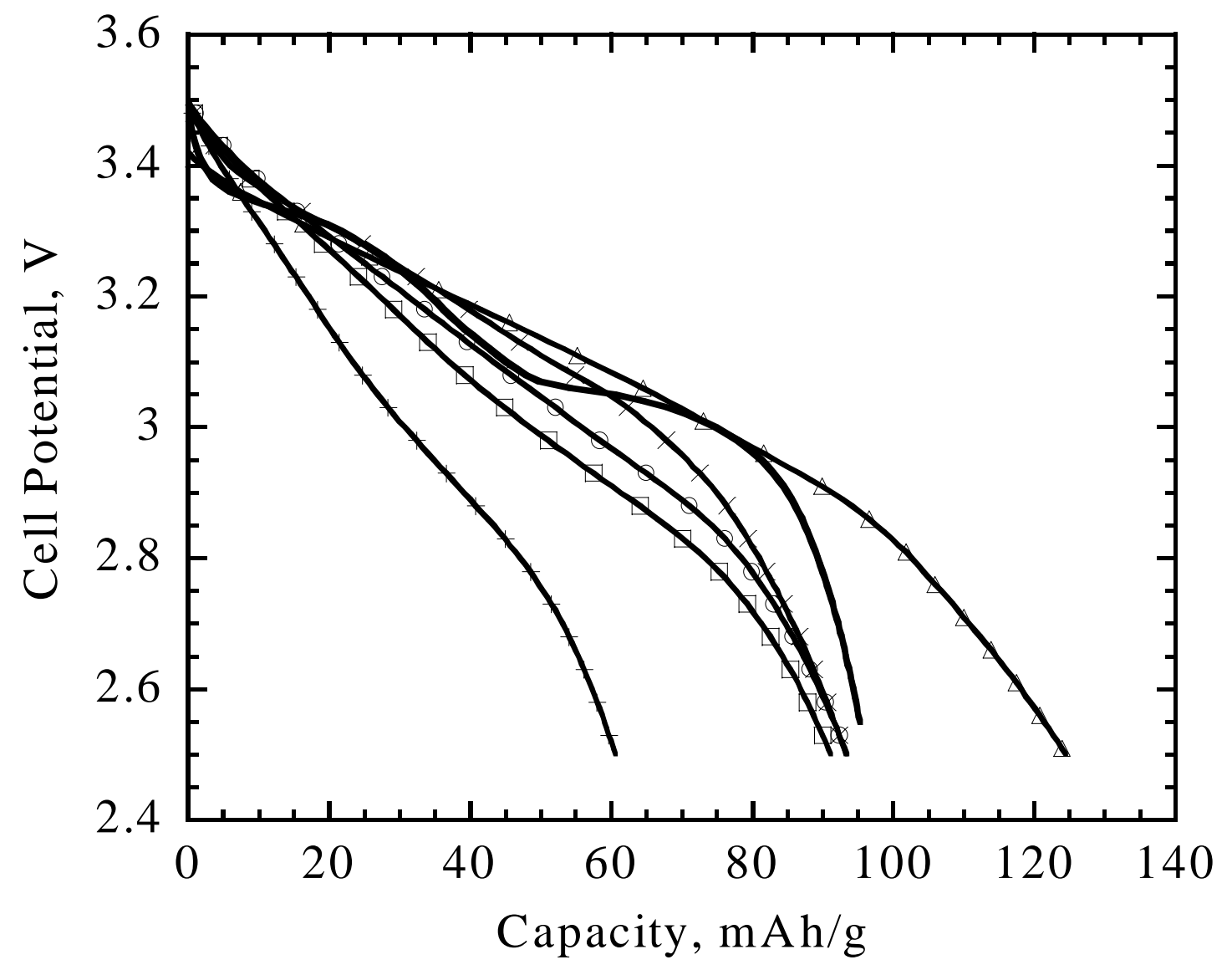

Figure 7 


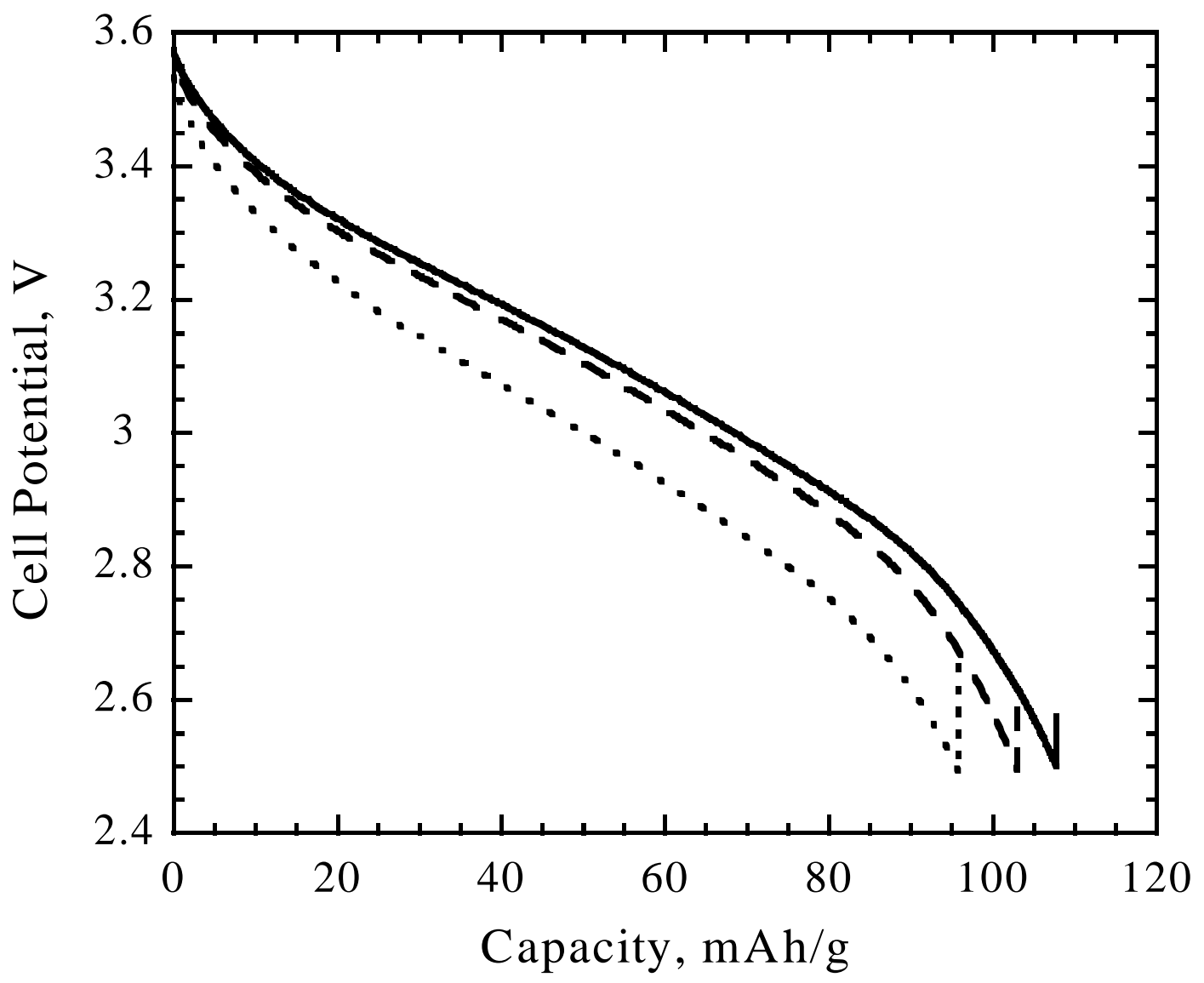

Figure 8 


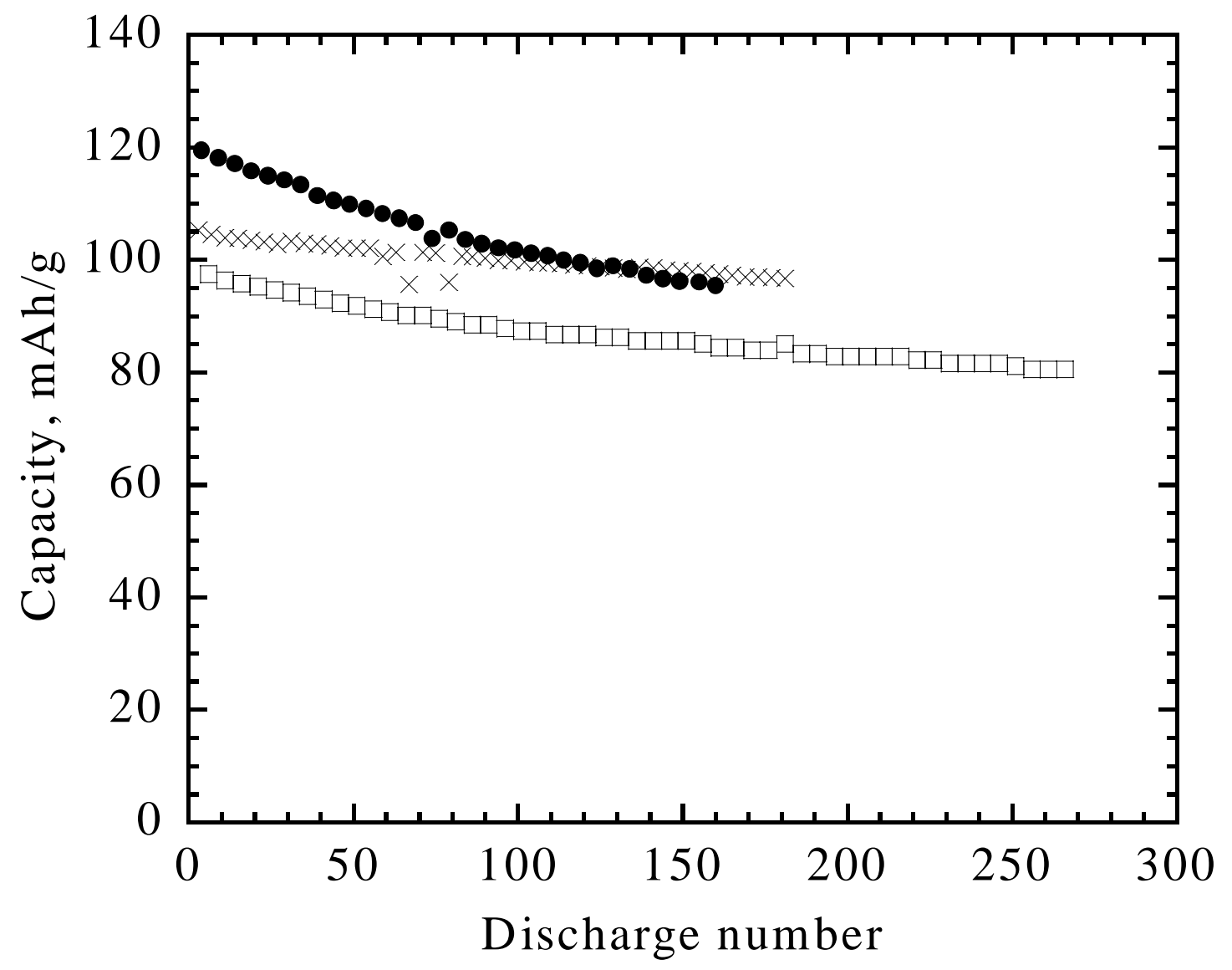

Figure 9 


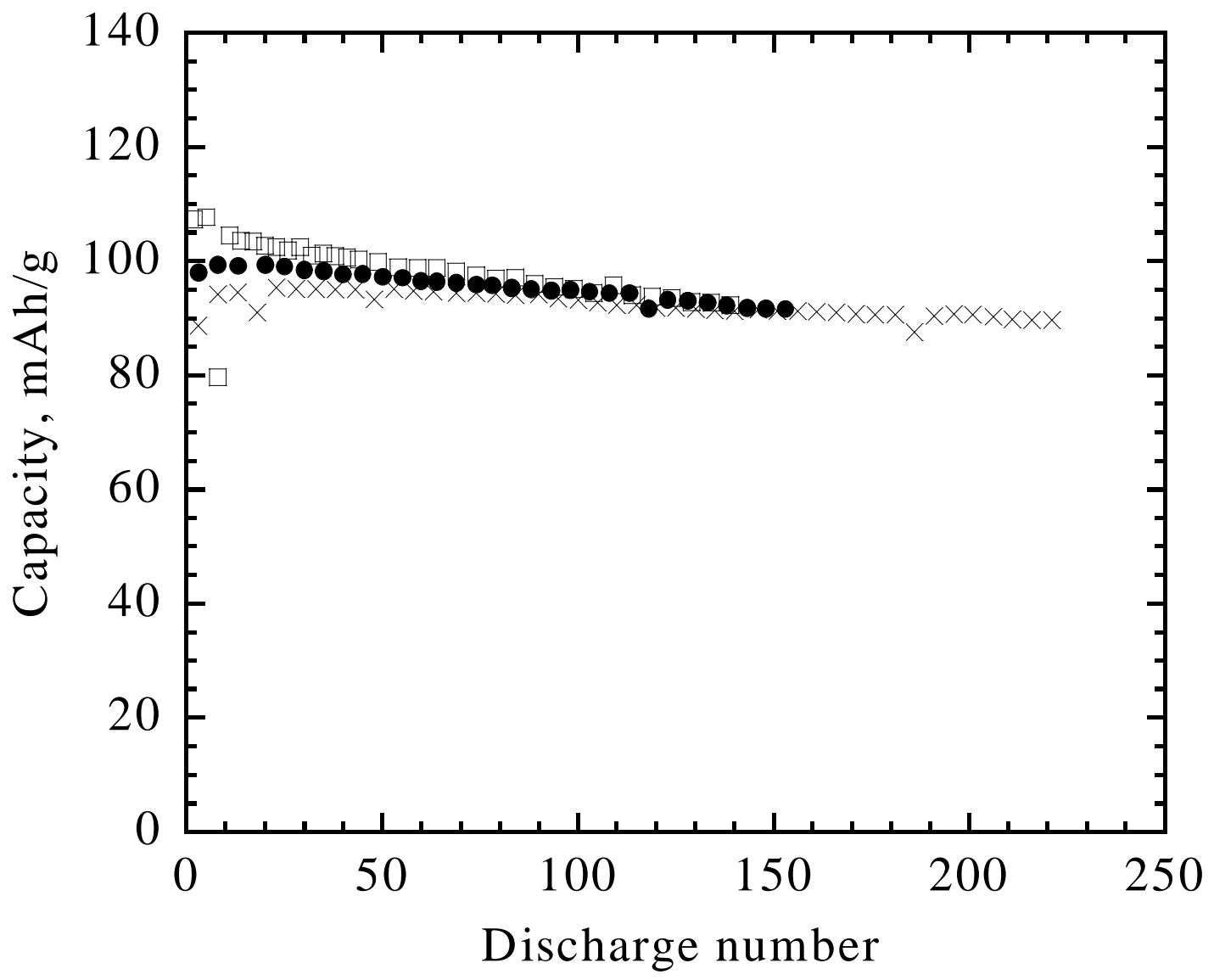

Figure 10 